\title{
FAKTOR-FAKTOR YANG BERHUBUNGAN DENGAN PERILAKU IBU BALITA MENIMBANG ANAKNYA KE POSYANDU
}

\author{
Achmad Djamil \\ Program Studi Kesehatan Masyarakat STIKES Mitra Lampung \\ Email: babedjamil@gmail.com
}

\begin{abstract}
Related Factors with The Behavior of Mothers to Weight Their Children to Health Centers. This study was to determine the factors associated with the behavior of mothers to weigh their children to health centers in the region of IHC Way Panji District of South Lampung Regency 2016. This research is a quantitative research with cross sectional approach.The results showed no correlation between knowledge ( $p$-value $=0.027$ ), there is a relationship attitude $(p$ value $=0.039)$, there was no distance relationship posyandu ( $\mathrm{p}$-value $=0.027)$, there is a correlation with health $(p$-value $=0.009)$, there is a relationship of family support ( $p$-value $=0.010)$, there was no relationship of friend support ( $\mathrm{p}$-value $=0.067$ ). No relationship support of community leaders ( $\mathrm{p}$-value $=0.013)$, and there is a relationship of support cadre $(\mathrm{p}$-value $=0.010)$ with the behavior of his mother weighed into the Posyandu.Conclusion: The results showed any correlation between knowledge $(p$-value $=0.027)$, there is a relationship attitude ( $p$ value $=0.039)$, there is a correlation with health ( $p$-value $=0.009$ ), there is a relationship of family support ( $p$ value $=0.010$ ), and there is a relationship of support cadre $(p$-value $=0.010)$ with the behavior of his mother weighed into the Posyandu.
\end{abstract}

Keywords: Attitude, Posyandu, Mother

\begin{abstract}
Abstrak: Faktor-faktor yang Berhubungan dengan Perilaku Ibu Balita Menimbang Anaknya ke Posyandu. Studi ini bertujuan ntuk mengetahui faktor-faktor yang berhubungan dengan perilaku ibu balita menimbang anaknya ke Posyandu di wilayah kerja Puskesmas Way Panji Kecamatan Way Panji Kabupaten Lampung Selatan tahun 2016. Jenis penelitian ini adalah penelitian kuantitatif dengan pendekatan cross-sectional. Hasil Menunjukkan ada hubungan pengetahuan ( $p$-value $=0,027)$ ada hubungan sikap ( $p$-value $=0,027)$, tidak ada hubungan jarak posyandu ( $p$-value $=0,027)$, ada hubungan tenaga kesehatan ( $p$-value $=0,009$ ), ada hubungan dukungan keluarga ( $p$-value $=0,010)$, tidak ada hubungan dukungan teman $(p$-value $=0,067)$. Ada hubungan dukungan tokoh masyarakat $(p$-value $=0,013)$ dan ada hubungan dukungan kader $(p$ value $=0,010$ ) dengan perilaku ibu menimbang anaknya ke Posyandu. Ada hubungan pengetahuan, sikap dan dukungan keluarga, tokoh masyarakat serta dukungan kader dengan perilaku ibu menimbang anaknya ke Posyandu.
\end{abstract}

Kata kunci: Perilaku, Posyandu, Ibu

Pertumbuhan pada balita dapat dipantau melalui penimbangan berat badan anak setiap bulan. Pemantauan pertumbuhan balita yang dilakukan setiap bulan menunjukkan bahwa persentase balita umur 6-59 bulan yang tidak pernah ditimbang dalam enam bulan terakhir cenderung meningkat dari 25,5\% (2007), 23,8\% (2010) menjadi 34,3\% (2013) (Kemenkes RI, 2013).

Usia antara 0-59 bulan adalah merupakan periode yang sangat penting bagi pertumbuhan anak, oleh sebab itu balita perlu ditimbang secara teratur sehingga dapat diikuti pertumbuhan berat badannya. Anak yang sehat akan tumbuh pesat, bertambah umur bertambah berat badannya.

Kemenkes RI (2012), Pemantauan berat badan balita akan berhasil dengan baik apabila ada partisipasi aktif dari masyarakat yang ditandai dengan tingkat kehadiran ibu menimbangkan anaknya di posyandu.

Untuk mencapai sasaran RJPMN 20102014 bidang kesehatan, pemerintah telah menetapkan rencana strategi 2010-2014 yang dibuat oleh Kementerian Kesehatan yaitu dengan menetapkan indikator 1) balita ditimbang berat badannya (D/S), 2) balita gizi buruk mendapatkan perawatan (Kemenkes RI, 2011).

Cakupan penimbangan ada kaitannya dengan faktor internal ibu balita seperti: tingkat pendidikan ibu balita, tingkat pengetahuan ibu balita, perilaku kesehatan, umur balita, status gizi balita di samping itu juga berkaitan dengan jarak posyandu serta peran petugas kesehatan, tokoh masyara kat, kader posyandu. Masalah lain yang 
berkaitan dengan kunjungan di posyandu antara lain: dana operasional dan sarana prasarana untuk menggerakkan kegiatan posyandu, tingkat pengetahuan kader dan kemampuan petugas dalam pemantauan pertumbuhan dan konseling, tingkat pemahaman keluarga danmasyarakat akan manfaat posyandu serta pelaksanaan pembinaan kader (Kemenkes RI, 2013).

Beberapa faktor yang dapat mempengaruhi perilaku ibu balita menimbang anaknya di posyandu antara lain: 1) umur balita dapat mempengaruhi partisipasi, hal ini disebabkan ibu balita merasa bahwa anaknya sudah berumur 9 bulan yang sudah mendapatkan imunisasi lengkap tidak perlu lagi datang ke posyandu, 2) jumlah anak, semakin banyak anggota keluarga, seorang ibu akan sulit mengatur waktu untuk hadir di posyandu, karena waktu akan habis untuk memberi perhatian dan kasih sayang untuk mengurus anak-anaknya di rumah, 3) tingkat pendidikan turut menentukan mudah tidaknya untuk menyerap dan memahami pengetahuan gizi, pendidikan dalam keluarga sangat diperlukan, hal ini terkait dengan informasi tentang kunjungan ibu balita ke posyandu dan rendahnya tingkat pendidikan erat kaitannya dengan perilaku ibu dalam memanfaatkan sarana kesehatan, dan 4) pengetahuan ibu, pengetahuan yang dimiliki seseorang akan membentuk suatu sikap dan menimbulkan suatu perilaku dalam kehidupan sehari-hari seperti hadir di posyandu (Kemenkes RI, 2013).

Berdasarkan profil Dinas Kesehatan Kabupaten Lampung Selatan tahun 2010 didapatkan data cakupan kunjungan balita ditimbang di posyandu secara keseluruhan yaitu sebesar 54,2\%, tahun 2011 sebesar 53,5\%, tahun 2012 sebesar 59,4\%, tahun 2013 sebesar 68,1\%. Cakupan balita ditimbang dari tahun 2010 sampai 2013 mengalami peningkatan walaupun belum mencapai target yang ditentukan yaitu $80 \%$. Sedangkan dari 26 puskesmas diwilayah kerja Dinas Kesehatan Kabupaten Lampung Selatan tahun 2014 cakupan balita ditimbang yang paling rendah sebesar $49 \%$ terdapat di Puskesmas Way Panji.

\section{METODE PENELITIAN}

Jenis penelitian ini merupakan penelitian kuantitatif, menggunakan desain cross sectional dimana pengumpulan variabel independen dan dependen diambil dalam waktu yang bersamaan.

Penelitian ini dilaksanakan di wilayah kerja Puskesmas Way Panji Kecamatan Way
Panji Kabupaten Lampung Selatan pada bulan Mei tahun 2016.

Populasi adalah keseluruhan objek penelitian atau objek yang diteliti. Populasi dalam penelitian ini adalah ibu yang mempunyai anak usia 6-59 bulan yang ada di 10 posyandu yang diteliti di 4 desa di wilayah kerja Puskesmas Way Panji Kecamatan Way Panji Kabupaten Lampung Selatan dengan jumlah populasi sebanyak 408 ibu balita.

Sampel dalam penelitian ini adalah ibu yang mempunyai anak usia 6-59 bulan tinggal di wilayah kerja Puskesmas Way Panji Kecamatan Way Panji Kabupaten Lampung Selatan.

Jenis data dalam penelitian ini adalah data primer. Teknik pengumpulan data dalam penelitian ini dilakukan dengan cara wawacara menggunakan kuesioner. Cara pengambilan sampel dalam penelitian ini menggunakan tehnik acak cluster sampling yang berarti penarikan dari populasi yang telah dikelompokkan terlebih dahulu dan dapat memilih individu secara langsung tetapi melalui kelompok yang dipilih secara acak. Agar sampel yang diperoleh merata dari tiap Posyandu, maka pembagian jumlah sampel diambil sesuai proposrsi dari masingmasing Posyandu. Perilaku ibu balita dalam menimbang anaknya ke Posyandu di wilayah kerja puskesmas Way Panji Kabupaten Lampung Selatan Tahun 2016.

\section{HASIL}

\section{A. ANALISIS UNIVARIAT}

Pada analisis univariat dipaparkan hasil dari distribusi frekuensi perilaku ibu, pengetahuan ibu, sikap ibu, jarak posyandu terhadap rumah, pembinaan tenaga kesehatan, dukungan keluarga, dukungan teman, dukungan tokoh masyarakat, dan dukungan kader terhadap ibu balita yang menimbang anaknya ke Posyandu. Seperti terlihat pada tabel di bawah ini. 
Tabel 1. Distribusi Frekuensi Variabel Penelitian dengan Perilaku Ibu Menimbang Bayi di Posyandu

\begin{tabular}{lrr}
\hline Variabel & \multicolumn{2}{l}{$\%$} \\
\hline Perilaku Ibu & 35 & \\
\hline Buruk & 163 & 82,3 \\
\hline Baik & & \\
\hline Pengetahuan Ibu & 13 & 21,7 \\
\hline Buruk & & \\
\hline Baik & 31 & \\
\hline Sikap Ibu & 167 & 15,7 \\
\hline Buruk & & \\
\hline Baik & 41 & 20,3 \\
\hline Jarak Posyandu & 157 & 79,3 \\
\hline Jauh & & \\
\hline Dekat & 19 & 9,6 \\
\hline Pembinaan tenaga kesehatan & 179 & 90,4 \\
\hline Buruk & & \\
\hline Baik & 23 & 11,6 \\
\hline Dukungan Keluarga & 175 & 88,4 \\
\hline Buruk & & \\
\hline Baik & 20 & 10,1 \\
\hline Dukungan Teman & 178 & 88,9 \\
\hline Buruk & & \\
\hline Baik & 36 & 18,2 \\
\hline Dukungan Tokoh Masyarakat & 162 & 81,8 \\
\hline Buruk & & \\
\hline Baik & 27 & 13,6 \\
\hline Dukungan kader & 171 & 86,4 \\
\hline Buruk & & \\
\hline Baik & & \\
\hline & & \\
\hline
\end{tabular}

Pada tabel 1 diketahui distribusi frekuensi perilaku ibu balita dalam menimbang anaknya ke Posyandu dengan baik sebesar $163(82,3 \%)$ dan buruk sebesar 35 (17,7\%); Distribusi frekuensi pengetahuan ibu balita dalam menimbang anaknya ke Posyandu dengan baik sebesar 155 $(78,3 \%)$ dan buruk sebesar 43 (21,7\%); Distribusi frekuensi sikap ibu balita dalam menimbang anaknya ke Posyandu dengan baik sebesar 167 $(84,3 \%)$ dan buruk sebesar 31 (15,7\%); Distribusi frekuensi jarak posyandu terhadap rumah ibu balita dalam menimbang anaknya ke posyandu dengan dekat sebesar $157(79,3 \%)$ dan jauh sebesar 41 (20,7\%); Distribusi frekuensi pembinaan tenaga kesehatan pada ibu balita dalam menimbang anaknya ke posyandu dengan baik sebesar $179(90,4 \%)$ dan buruk sebesar 19 $(9,6 \%)$; Distribusi frekuensi dukungan keluarga pada ibu balita dalam menimbang anaknya ke posyandu dengan baik sebesar $175(88,4 \%)$ dan buruk sebesar 23 (11,6\%); Distribusi frekuensi dukungan teman pada ibu balita dalam menimbang anaknya ke posyandu dengan baik sebesar 178 (89,9\%) dan buruk sebesar 20 $(10,1 \%)$; Distribusi frekuensi dukungan tokoh masyarakat pada ibu balita dalam menimbang anaknya ke posyandu dengan baik sebesar 162 $(81,8 \%)$ dan buruk sebesar 36 (18,2\%); Distribusi frekuensi dukungan kader pada ibu balita dalam menimbang anaknya ke posyandu dengan baik sebesar $171(86,4 \%)$ dan buruk sebesar 27 $(13,6 \%)$. 


\section{B. ANALISIS BIVARIAT}

Tabel 2. Hubungan antara Pengetahuan Ibu, Sikap Ibu, Jarak Ke Posyandu, Pembinaan Tenaga Kesehatan, Dukungan Keluarga, Dukungan Teman, Dukungan Tokoh Masyarakat, dan Dukungan Kader dengan Perilaku Ibu Balita dalam Menimbang Anaknya ke Posyandu

\begin{tabular}{|c|c|c|c|c|c|c|c|c|}
\hline \multirow[t]{2}{*}{ Variabel } & \multicolumn{4}{|c|}{$\begin{array}{c}\text { Perilaku ibu dalam menimbang } \\
\text { anaknya ke Posyandu }\end{array}$} & \multirow{2}{*}{\multicolumn{2}{|c|}{ Total }} & \multirow[t]{3}{*}{$\begin{array}{l}\text { OR } \\
\text { CI } 95 \%\end{array}$} & \multirow[t]{3}{*}{$\begin{array}{c}p- \\
\text { value }\end{array}$} \\
\hline & \multicolumn{2}{|c|}{ buruk } & \multicolumn{2}{|c|}{ baik } & & & & \\
\hline Pengetahuan & $\mathbf{n}$ & $\%$ & $\mathbf{n}$ & $\%$ & $\mathbf{n}$ & $\%$ & & \\
\hline Buruk & 13 & 30,2 & 30 & 69,8 & 43 & 100 & $2.620-1,187$ & 0,027 \\
\hline Baik & 22 & 14,2 & 133 & 85,8 & 155 & 100 & & \\
\hline \multicolumn{9}{|l|}{ Sikap } \\
\hline Buruk & 10 & 32,3 & 21 & 67,7 & 31 & 100 & 2.705 & 0,037 \\
\hline Baik & 25 & 15,0 & 142 & 85,0 & 167 & 100 & $(1,139-6,422)$ & \\
\hline \multicolumn{9}{|l|}{ Jarak Posyandu } \\
\hline Jauh & 12 & 29,3 & 29 & 70,7 & 41 & 100 & & 0,051 \\
\hline Dekat & 23 & 14,6 & 134 & 85,4 & 157 & 100 & & \\
\hline \multicolumn{9}{|l|}{$\begin{array}{l}\text { Pembinaan Tenaga } \\
\text { Kesehatan }\end{array}$} \\
\hline Buruk & 8 & 42,1 & 11 & 57,9 & 19 & 100 & 4.094 & 0,009 \\
\hline Baik & 27 & 15,1 & 152 & 84,9 & 179 & 100 & $(1,508-11,112)$ & \\
\hline \multicolumn{9}{|l|}{ Dukungan Keluarga } \\
\hline Buruk & 9 & 39,2 & 14 & 60,9 & 23 & 100 & 3.684 & 0,010 \\
\hline Baik & 26 & 14,9 & 149 & 85,1 & 175 & 100 & $(1,446-9,387)$ & \\
\hline \multicolumn{9}{|l|}{ Dukungan Teman } \\
\hline Buruk & 7 & 35 & 13 & 65 & 20 & 100 & & 0,067 \\
\hline Baik & 28 & 15,7 & 150 & 84,3 & 178 & 100 & & \\
\hline \multicolumn{9}{|l|}{$\begin{array}{l}\text { Dukungan Tokoh } \\
\text { Masyarakat }\end{array}$} \\
\hline Buruk & 12 & 33,3 & 24 & 66,7 & 36 & 100 & 3.022 & 0,013 \\
\hline Baik & 23 & 14,2 & 139 & 85,8 & 162 & 100 & $(1,329-6,871)$ & \\
\hline \multicolumn{9}{|l|}{ Dukungan Kader } \\
\hline Buruk & 10 & 37 & 17 & 63 & 27 & 100 & 3.453 & 0,010 \\
\hline Baik & 25 & 14,6 & 146 & 85,4 & 171 & 100 & $(1,412-8,356)$ & \\
\hline
\end{tabular}

\section{PEMBAHASAN}

1. Hubungan Pengetahuan Ibu Balita dengan Perilaku Ibu Dalam Menimbang Anaknya ke Posyandu

Hasil uji statistik analisis bivariat dalam penelitian ini menunjukkan nilai $p$-value $=0,027$, yang berarti bahwa ada hubungan yang signifikan antara pengetahuan ibu dengan perilaku ibu balita dalam menimbang anaknya ke posyandu di wilayah kerja Puskesmas Way Panji Kabupaten Lampung Selatan tahun 2016, sedangkan nilai $\mathrm{OR}=2,620$, artinya ibu balita yang mempunyai pengetahuan yang baik mempunyai peluang berperilaku baik dalam menimbang anaknya ke posyandu sebesar 2,62 kali dibandingkan dengan ibu balita yang mempunyai pengetahuan buruk.

Penelitian ini sejalan dengan penelitian yang dilakukan La Ode tahun 2013 yang menyatakan bahwa terdapat hubungan yang signifikan antara pengetahuan ibu dengan perilaku ibu balita berkunjung ke posyandu,
Tetapi terdapat juga penelitian yang dilakukan oleh Heriani tahun 2010 yaitu tidak terdapat hubungan antara pengetahuan ibu dengan frekuensi kunjungan balita ke Posyandu.

Berdasarkan teori dari Lawrence Green tahun 1980 dalam Notoatmodjo telah dijelaskan bahwa peningkatan pengetahuan tidak selalu menjadi penyabab dari perubahan perilaku seseorang, tetapi sangat berkaitan dengan penentu awal seseorang untuk berperilaku.

Menurut pendapat peneliti bahwa ibu balita yang mempunyai pengetahuan yang baik tentang kesehatan belum tentu memberikan perilaku yang baik pada ibu balita untuk melakukan penimbangan ke posyandu.Setiap pengetahuan sesorang dipengaruhi beberapa faktor yaitu seperti pendidikan, pekerjaan, umur, minat, pengalaman, kebudayaan lingkungan sekitar dan informasi.Informasi yang dimaksud yaitu kemudahan untuk memperoleh suatu informasi sehingga mempercepat seseorang memperoleh pengetahuan baru. 
Dengan demikian perlu adanya peningkatan pemahaman ibu tentang manfaat posyandu melalui sarana media informasi seperti poster, leaflet, spanduk dan yang lainnya yang berguna untuk meningkatkan pengetahuan ibu balita tentang posyandu sehingga perilaku ibu balita tertarik berkunjung ke posyandu yang ada di wilayah kerja puskesmas Way Panji.

\section{Hubungan Sikap Ibu Balita dengan Perilaku Ibu Dalam Menimbang Anaknya ke Posyandu}

Hasil uji statistik analisis bivariat dalam penelitian ini menunjukkan nilai $p$-value $=0,039$, yang berarti bahwa ada hubungan yang signifikan antara sikap ibu dengan perilaku ibu balita dalam menimbang anaknya ke posyandu di wilayah kerja UPT Puskesmas Way Panji Kabupaten Lampung Selatan tahun 2016, sedangkan nilai $\mathrm{OR}=2,705$, artinya ibu balita yang mempunyai sikap yang baik mempunyai peluang berperilaku baik dalam menimbang anaknya ke posyandu sebesar 2,7 kali dibandingkan dengan ibu balita yang mempunyai sikap buruk.

Penelitian ini sejalan dengan yang dilakukan Jannah (2012) yaitu terdapatnya hubungan antara variabel sikap dengan kunjungan ibu ke Posyandu.

Menurut pendapat peneliti, sikap merupakan produk dari proses sosialisasi dimana seseorang bereaksi sesuai dengan rangsangan yang diterimanya. Pengertian sikap berdasarkan unsur kepribadian adalah berkaitan dengan motif yang mendasari tingkah laku seseorang berdasarkan keyakinan, kebiasaan, pendapat dan konsep. Sikap memiliki unsur penilaian dan reaksi afektif yang tidak sama dengan motif, akan tetapi mengahsilkan motif tertentu yang menghasilkan perilaku. Penilaian individu tentang objek diperoleh melalui pengalaman langsung berdasarkan interaksi.

Dengan demikian sikap pada ibu balita dalam menimbang anaknya ke posyandu di wilayah kerja puskesmas Way Panji harus selalu diberikan apresiasi berupa hadiah terhadap anaknya yang ditimbang sampai umur 5 tahun, misalnya dengan memberikan piagam pada anaknya bila sampai menimbang anaknya umur 5 tahun, memberikan multivitamin setiap datang ke posyandu, bersikap ramah, jadwal penimbangan selalu tepat sehingga sikap ibu balita dalam menimbang anaknya ke posyandu dapat meningkat.

\section{Hubungan AntaraJarak Posyandu dengan Perilaku Ibu Balita Dalam Menimbang Anaknya ke Posyandu}

Hasil uji statistik analisis bivariat dalam penelitian ini menunjukkan nilai $p$-value $=0,051$, yang berarti bahwa tidak ada hubungan yang signifikan antara jarak posyandu dengan perilaku ibu balita dalam menimbang anaknya ke posyandu di wilayah kerja UPT Puskesmas Way Panji Kabupaten Lampung Selatan tahun 2016.

Penelitian ini sejalan dengan penelitian yang dilakukan oleh Nofianti tahun 2012 yaitu tidak ada hubungan antara jarak posyandu dengan perilaku pemanfaatan posyandu oleh ibu balita.Selain itu terdapat juga penelitian yang sejalan tidak adanya hubungan yang bermakna antara jarak posyandu dengan perilaku ibu ke posyandu (Suryaningsih, 2012).

Menurut pendapat peneliti dugaan tidak ada hubungan antara jarak rumah ibu untuk ke posyandu berdasarkan hasil observasi dan wawancara yang dilakukan sebagaian besar ibu tidak mengetahui jarak tempuh rumahnya ke posyandu, sehingga dengan ketidak tahuan tersebut bisa jadi ibu tidak memiliki kepedulian untuk jarak jauh atau dekat ibu tetap datang ke posyandu, hal ini juga diperkuat sesuai hasil didapatkan 70,7\% ibu yang memiliki jarak rumah jauh dengan posyandu tapi perilaku menimbangnya tetap baik.

\section{Hubungan Pembinaan dari Tenaga Kesehatan dengan Perilaku Ibu Balita Dalam Menimbang Anaknya ke Posyandu}

Hasil uji statistik analisis bivariat dalam penelitian ini menunjukkan nilai $p$-value $=0,009$, yang berarti bahwa ada hubungan yang signifikan antara pembinaan dari tenaga kesehatan dengan perilaku ibu balita dalam menimbang anaknya ke posyandu di wilayah kerja UPT Puskesmas Way Panji Kabupaten Lampung Selatan tahun 2016, sedangkan nilai $\mathrm{OR}=4,094$, artinya ibu balita yang mendapat pembinaan dari tenaga kesehatan dengan baik mempunyai peluang berperilaku baik dalam menimbang anaknya ke posyandu sebesar 4,09 kali dibandingkan dengan ibu balita yang mendapat pembinaan dari tenaga kesehatan dengan buruk.

Penelitian ini sejalan dengan yang dilakukan oleh Suryaningsih tahun 2012 yaitu terdapat hubungan antara pembinaan dari tenaga kesehatan dengan kunjungan ibu ke Posyandu.Berdasarkan penelitian yang dilakukan oleh Reihana dkk tahun 2014 yaitu terdapat hubungan antara kehadiran tenaga kesehatan dengan partisipasi ibu untuk menimbang anaknya ke Posyandu. 
Menurut peneliti seorang berperilaku sehat yaitu berdasarkan kemampuan tenaga kesehatan.Sebagai tenaga kesehatan yang terampil sudah seharusnya memiliki pengetahuan yang cukup serta melakukan pemberian pelayanan kesehatan kepada masyarakat dengan memberikan informasi dalam bentuk penyuluhan. Kemampuan tenaga kesehatan ini dilihat dari kemapuan petugas puskesmas.

\section{Hubungan Dukungan Keluarga dengan Perilaku Ibu Balita Dalam Menimbang Anaknya ke Posyandu}

Hasil uji statistik analisis bivariat dalam penelitian ini menunjukkan nilai $p$-value $=0,010$, yang berarti bahwa ada hubungan yang signifikan antara dukungan keluarga dengan perilaku ibu balita dalam menimbang anaknya ke posyandu di wilayah kerja UPT Puskesmas Way Panji Kabupaten Lampung Selatan tahun 2016, sedangkan nilai $\mathrm{OR}=3,664$, artinya ibu balita yang mendapat dukungan dari keluarga dengan baik mempunyai peluang berperilaku baik dalam menimbang anaknya ke posyandu sebesar 3,66 kali dibandingkan dengan ibu balita yang mendapat dukungan keluarga dengan buruk.

Penelitian ini sejalan dengan penelitian yang dilakukan oleh Reihana dkk tahun 2014 yaitu terdapatnya hubungan antara dukungan keluarga dengan partisipasi ibu untuk menimbang anaknya ke Posyandu.Selain itu terdapat juga penelitian yang dilakukan oleh Hairunida tahun 2012 yaitu tidak terdapat hubungan antara dukungan keluarga dengan perilaku kunjungan ke Posyandu.

Menurut peneliti faktor penguat untuk seseorang berperilaku sehat yaitu berdasarkan dukungan keluarga. Ibu akan aktif ke Posyandu jika ada dorongan dari orang terdekat termasuk keluarga. Keluarga merupakan sistem dasar dimana perilaku sehat dan perawatan kesehatan diatur, dilakukan, dan diamankan keluarga memberikan perawatan kesehatan bersifat preventif dan bersama-sama merawat anggota keluarga.Keluarga memilki tanggung jawab utama untuk memulai dan mengkoordinasikan pelayanan yang diberikan oleh petugas kesehatan.

\section{Hubungan Dukungan Teman dengan Perilaku Ibu Balita Dalam Menimbang Anaknya ke Posyandu}

Hasil uji statistik analisis bivariat dalam penelitian ini menunjukkan nilai $p$-value $=0,067$, yang berarti bahwa tidak ada hubungan yang signifikan antara dukungan teman dengan perilaku ibu balita dalam menimbang anaknya ke posyandu di wilayah kerja UPT Puskesmas Way Panji Kabupaten Lampung Selatan tahun 2016.

Menurut peneliti dalam faktor penguat untuk seseorang berperilaku sehat yaitu berdasarkan dukungan peers atau teman, dalam penelitian ini dukungan teman dilihat dari ajakan tetangga atau sesama ibu balita yang mengajak responden untuk berkunjung ke Posyandu. Untuk variabel ini dukungan teman tidak berpengaruh terhadap perilaku ibu untuk ke posyandu, didasarkan bahwa ibu yang tidak mendapatkan dukungan baik dari teman untuk menimbang anaknya ke posyandu ternyata tetap menimbang anaknya ke posyandu, hal ini mengindikasikan dukungan teman tidak berpengaruh terhadap perilaku ibu menimbang anaknya ke posyandu.

\section{Hubungan Dukungan Tokoh Masyarakat dengan Perilaku Ibu Balita Dalam Menimbang Anaknya ke Posyandu}

Hasil uji statistik menunjukkan nilai $p$ value $=0,013$, yang berarti bahwa ada hubungan yang signifikan antara dukungan tokoh masyarakat dengan perilaku ibu balita dalam menimbang anaknya ke posyandu di wilayah kerja UPT Puskesmas Way Panji Kabupaten Lampung Selatan tahun 2016, sedangkan nilai $\mathrm{OR}=3,022$, artinya ibu balita yang mendapat dukungan dari tokoh masyarakat dengan baik mempunyai peluang berperilaku baik dalam menimbang anaknya ke posyandu sebesar 3,02 kali dibandingkan ibu balita yang mendapat dukungan tokoh masyarakat dengan buruk.

Penelitian ini sejalan dengan penelitian Hairunida tahun 2012 bahwa terdapat hubungan antara dukungan tokoh masyarakat dengan perilaku kunjungan ibu balita ke Posyandu.Selain itu juga terdapat penelitian yang dilakukan oleh Purnamasari dkk tahun 2011 bahwa terdapat hubungan antara dukungan tokoh masyarakat dengan kunjungan ibu balita ke Posyandu.

Menurut pendapat peneliti faktor penguat untuk seseorang berperilaku sehat yaitu adanya tokoh masyarakat memiliki peran yang sangat besar dalam mempengaruhi perilaku masyarakat didalam pengambilan keputusan termasuk keputusan dalam perilaku kesehatan, seperti perilaku membawa balita ke Posyandu.

Dengan demikian di wilayah kerja UPT Puskesmas Way Panji tokoh masyarakat perlu di advokasi oleh tenaga kesehatan agar mendorong dan memotivasi ibu balita untuk menimbang anaknya sampai umur 5 tahun di posyandu. 


\section{Hubungan Dukungan Kader dengan Perilaku Ibu Balita Dalam Menimbang Anaknya ke Posyandu}

Hasil uji statistik analisis bivariat dalam penelitian ini menunjukkan nilai $p$-value $=0,010$, yang berarti bahwa ada hubungan yang signifikan antara dukungan kader dengan perilaku ibu balita dalam menimbang anaknya ke posyandu di wilayah kerja UPT Puskesmas Way Panji Kabupaten Lampung Selatan tahun 2016, sedangkan nilai $\mathrm{OR}=3,435$, artinya ibu balita yang mendapat dukungan dari kader dengan baik mempunyai peluang berperilaku baik dalam menimbang anaknya ke posyandu sebesar 3,43 kali dibandingkan dengan ibu balita yang mendapat dukungan kader dengan buruk.

Penelitian ini sejalan dengan penelitian yang dilakukan oleh Ari dkk yaitu terdapat hubungan antara peran serta kader dengan keaktifan ibu membawa balitanya ke Posyandu.

Menurut pendapat peneliti bahwa dukungan yang diberikan oleh kader terutama kader posyandu kepada ibu balita untuk membawa anaknya ke posyandu sudah menjadi tugas kader untuk memberikan informasi kesehatan terkait tumbuh kembang, sesuai tugas kader yang ditempatkan di meja keempat dalam memberikan penyuluhan-penyuluhan tentang kesehatan.

Dengan demikian diharapkan kader posyandu yang ada di wilayah kerja UPT Puskesmas Way Panji lebih aktif lagi dalam melaksanakan kegiatan posyandu baik dalam hal memberikan informasi, penyuluhan tentang keuntungan menimbang anak di posyandu.

\section{SIMPULAN}

Berdasarkan hasil penelitian dan pembahasan, dapat disimpulkan:

1. Distribusi frekuensi perilaku ibu balita dalam menimbang anaknya ke Posyandu dengan baik sebesar $163(82,3 \%)$ dan buruk sebesar $35(17,7 \%)$

2. Distribusi frekuensi pengetahuan ibu balita dalam menimbang anaknya ke Posyandu dengan baik sebesar 155 (78,3\%) dan buruk sebesar $43(21,7 \%)$.

3. Distribusi frekuensi sikap ibu balita dalam menimbang anaknya ke Posyandu dengan baik sebesar $167(84,3 \%)$ dan buruk sebesar $31(15,7 \%)$.

4. Distribusi frekuensi jarak posyandu terhadap rumah ibu balita dalam menimbang anaknya ke posyandu dengan dekat sebesar 157 $(79,3 \%)$ dan jauh sebesar $41(20,7 \%)$.
5. Distribusi frekuensi pembinaan tenaga kesehatan pada ibu balita dalam menimbang anaknya ke posyandu dengan baik sebesar $179(90,4 \%)$ dan buruk sebesar $19(9,6 \%)$.

6. Distribusi frekuensi dukungan keluarga pada ibu balita dalam menimbang anaknya ke posyandu dengan baik sebesar $175(88,4 \%)$ dan buruk sebesar $23(11,6 \%)$.

7. Distribusi frekuensi dukungan teman pada ibu balita dalam menimbang anaknya ke posyandu dengan baik sebesar $178(89,9 \%)$ dan buruk sebesar $20(10,1 \%)$.

8. Distribusi frekuensi dukungan tokoh masyarakat pada ibu balita dalam menimbang anaknya ke posyandu dengan baik sebesar $162(81,8 \%)$ dan buruk sebesar $36(18,2 \%)$.

9. Distribusi frekuensi dukungan kader pada ibu balita dalam menimbang anaknya ke posyandu dengan baik sebesar $171(86,4 \%)$ dan buruk sebesar $27(13,6 \%)$.

10. Terdapat hubungan antara pengetahuan dengan perilaku ibu menimbang anaknya ke posyandu dengan nilai $p$-value $=0,027$ dan nilai $\mathrm{OR}=2,620$.

11. Terdapat hubungan antara sikap dengan perilaku ibu menimbang anaknya ke posyandu dengan nilai $p$-value $=0,039$ dan nilai $\mathrm{OR}=2,705$.

12. Terdapat hubungan antara pembinaan tenaga kesehatan dengan perilaku ibu menimbang anaknya ke posyandu dengan nilai $p$ value $=0,009$ dan nilai $\mathrm{OR}=4,094$.

13. Terdapat hubungan antara dukungan keluarga dengan perilaku ibu menimbang anaknya ke posyandu dengan nilai $p$ value $=0,010$ dan nilai $\mathrm{OR}=3,684$.

14. Terdapat hubungan antara dukungan tokoh masyarakat dengan perilaku ibu menimbang anaknya ke posyandu dengan nilai $p$ value $=0,013$ dan nilai $\mathrm{OR}=3,022$.

15. Terdapat hubungan antara dukungan kader dengan perilaku ibu menimbang anaknya ke posyandu dengan nilai $p$-value $=0,010$ dan nilai $\mathrm{OR}=3,435$.

16. Tidak ada hubungan antara jarak posyandu dengan perilaku ibu menimbang anaknya ke posyandu dengan nilai $p$-value $=0,051$.

17. Tidak ada hubungan antara dukungan teman dengan perilaku ibu menimbang anaknya ke posyandu dengan nilai $p$-value $=0,067$.

18. Faktor yang paling berhubungan dengan perilaku ibu menimbang anaknya ke posyandu adalah variabel pembinaan tenaga kesehatan dengan nilai $p$-value $=0,009$ dan nilai $\mathrm{OR}=4,094$. 


\section{DAFTAR PUSTAKA}

Dinas Kesehatan Kabupaten Lampung Selatan. 2010. Profil Kesehatan Dinas Kesehatan Kabupaten Lampung Selatan tahun 2010. Lampung Selatan.

Heriani, Farida 2010. Hubungan Pendidikan, Pekerjaan, Pengetahuan dan Kepuasan Ibu Terhadap Posyandu dengan Frekuensi Kunjungan Balita ke Posyandu. Lampung. FK.Universitas Lampung Mangkurat.

Hairunida, Elida BR Purba.2012. Faktor Yang Berhubungan Dengan Perilaku Kunjungan Ke Posyandu Pada Ibu Balita di Wilayah Kerja Puskesmas Pancoran Mas kota Depok Tahun 2012. FKM UI.

Jannah, Murifatul. 2012. Pengaruh Tingkat Pendidikan, Pengetahuan Jarak Tempat Tinggal dan Sikap Ibu Kepada Pelayanan Petugas Puskesmas Terhadap Frekuensi Kunjungan Ibu ke Posyandu di Kabupaten Lamongan. Universitas Negeri Surabaya.

Kemenkes RI. 2011. Panduan Penyelenggaraan Pemberian Makanan Tambahan Pemulihan Bagi Balita Gizi Kurang. Bantuan Operasional Kesehatan. Jakarta: Ditjend Bina Gizi dan KIA.

Kemenkes RI. 2012. Ayo ke Posyandu Setiap Bulan.Jakarta: Pusat Promosi Kesehatan Kementerian Kesehatan RI.

Pelatihan - 2012. Kurikulum dan Modul Kader Posyandu. Jakarta: Kemenkes RI.
2014. Rencana Kerja Pembinaan Gizi Masyarakat. Kemenkes RI, Jakarta.

2014. Pedoman Pelayanan Gizi di Puskesmas. Jakarta: Kemenkes RI Direktorat Bina Gizi dan KIA. 2011. Pedoman Umum Pengelolaan Posyandu. Kemenkes RI.Jakarta: Kelompok Kerja Operasional Posyandu.

. 2013. Buku Panduan Kader Posyandu Menuju Keluarga Sadar Gizi. Jakarta: Kemenkes RI. . 2013. Riset Kesehatan Dasar (Riskedas 2013). Jakarta: Litbang Kemenkes RI.

La Ode, Muhammad Syahir. 2013. Faktor-Faktor Yang Berhubungan dengan Kunjungan ibu Yang Mempuyai Balita ke Posyandu diWilayah Kerja Puskesmas Tamanlarea Makasar. STIKES Nani Hasanuddin Makasar.

Nofianti, Susi. 2012. Faktor-Faktor yang Berhubungan dengan Perilaku Pemanfaatan Posyandu Oleh Ibu Balita di Wilayah Kerja Puskesmas Maek Kabupaten Lima Puluh Kota Tahun 2012.

Suryaningsih, Hestri. 2012. Faktor-Faktor Yang Berhubungan dengan Perilaku Ibu Bayi dan Balita ke Posyandu di Puskesmas Kemiri Muka Kota Depok Tahun 2012. FKM UI. 